\title{
ANALISIS POTENSI SUMBER DAYA MANUSIA NAGARI PARIANGAN KABUPATEN TANAH DATAR
}

\author{
Vandi Vahrul $^{1}$, Yurni Suasti ${ }^{2}$, Febriandi $^{2}$ \\ Program Studi Pendidikan Geografi, \\ Fakultas Ilmu Sosial, Universitas Negeri Padang \\ Email: vandyfahrul@gmail.com
}

\begin{abstract}
Abstrak
Penelitian ini bertujuan untuk mendapatkan data dan informasi tentang Potensi Sumber Daya Manusia Nagari Pariangan Kabupaten Tanah Datar yang berkaitan dengan (1) Kepadatan Penduduk, (2) Usia, (3) Tingkat Pendidikan, (4) Mata Pencaharian Pokok, (5) Agama dan Aliran Kepercayaan, (6) Kewarganegaraan, (7) Etnis dan Suku Bangsa, dan (8)Tenaga Kerja. Penelitian ini adalah penelitian deskriptif dengan menggunakan metode analisis data sekunder dengan menggunakan teknik skoring. Wilayah penelitiannya meliputi Nagari Pariangan yang terdiri dari empat jorong yaitu, Guguak, Padang Panjang, Pariangan, dan Sikaladi.

Hasil penelitian (1) Kepadatan Penduduk termasuk kedalam kategori penduduk kurang padat sampai dengan sangat padat, (2) kelompok usia $25-50 \%$ penduduk berusia 18-56 tahun, (3)Tingkat Pendidikan, kelompok umur 7-18 tahun yang tidak sekolah kurang dari $10 \%$, Kelompok umur 12-56 tahun yang tidak pernah sekolah kurang dari 10 $\%$, kelompok umur 12-56 tahun tidak tamat SD kurang dari 10\%, 12-56 tahun yang tidak tamat SLTP masing- kurang dari 30\%, kelompok umur 18-56 tahun yang tidak tamat SLTA kurang dari 15\%, (4) Jumlah sebaran mata pencaharian pokok berkisar 5-10 jenis mata pencaharian pokok, sebahagian besar penduduk bermata pencaharian petani, peternak,pedagang, (5) sebaran agama penduduk, semua penduduk beragama ISLAM, (6) Kewarganegaraan penduduk, semua penduduk berkewarganegaraan Indonesia (WNI), (7) Pembauran etnis/suku bangsa masyarakat, semua penduduk berasal dari satu etnis/suku bangsa yakni suku Minang, (8) Tenaga kerja dilihat dari, kelompok umur 18-56 tahun penduduk yang tidak bekerja rata-rata di bawah 5\%, kelompok umur 18-56 tahun yang bekerja lebih dari 50\%, sedangkan angka ketergantungan kerja penduduk usia 18-56 tahun yang bekerja dengan penduduk 0-56 tahun ke atas yang tidak bekerja mencapai 50$90 \%$.
\end{abstract}

Kata Kunci: Potensi Sumber Daya Manusia

\section{Abstract}

This study aimed to obtain data and information on the Potential Human Resources Nagari Pariangan Tanah Datar relating to (1) Population Density, (2) age, (3) Level of Education, (4) Livelihood Principal, (5) Religion and Beliefs, (6) Citizenship, (7) Ethnic and Tribal, and (8) Labor. This study was a descriptive study using secondary data analysis using scoring techniques. Research region includes Nagari Pariangan consisting of four ellipse that is, Guguak, Padang Panjang, Pariangan, and Sikaladi.

Results of the study (1) Population Density more than 100 inhabitants / km2, (2) the age group of 25-50\% of the population aged 18-56 years, (3) education level, age group 7-18 years are out of school less than 10\%, the age group of 12-56 years who have never attended school less than 10\%, the age group of 12-56 years do not complete

\footnotetext{
${ }^{1}$ Mahasiswa Program Studi Pendidikan Geografi untuk Wisuda September 2017

${ }^{2}$ Dosen Jurusan Geografi Fakultas Ilmu Sosial Universitas Negeri Padang
} 
primary school less than 10\%, 12-56 years who had not completed junior high school each less than 30\%, the age group 18-56 years who did not graduate from high school less than 15\%, (4) Total distribution of basic livelihood livelihood range of 5-10 kinds of goods, largely residents of livelihood of farmers, ranchers, merchants, (5) religious distribution of the population, all the inhabitants of religion ISLAM, ( 6) Citizenship residents, all residents of an Indonesian citizen (citizen), (7) the intermingling of ethnic / tribal people, all residents are from one ethnic / tribal namely Minang tribe, (8) labor viewed from, the age group 18-56 years residents who do not work on average below 5\%, the age group of 18-56 tear who work more than 50\%, whereas the number of work-age population dependency 18-56 years of working with people 0-56 years and over who did not work reaches $50-90 \%$

\section{Keyword: Potential Human Resources}

\section{PENDAHULUAN}

Potensi sumber daya manusia pada hakekatnya merupakan salah satu modal dasar pembangunan nasional. Perkembangan dunia usaha yang semakin pesat pada saat ini menyebabkan begitu banyaknya permasalahan yang harus dihadapi. Salah satu permasalahan yang sering dihadapi perusahaan di Indonesia adalah aspek sumber daya manusia yang digunakan untuk memanfaatkan teknologi yang ada.

Dalam sebuah sumber daya manusia merupakan salah satu faktor yang sangat penting bahkan tidak dapat dilepaskan dari sebuah organisasi, baik institusi maupun lainya. Namun demikian paradigma pembangunan dari terdahulu sudah mengembangkan konsep-konsep pembangunan berbasis lokal, namun masih menggunakan bentuk kelembagaan yang bersifat umum dan keberhasilannya menggunakan ukuran yang terbatas pada indikator fisik (materi) dan ekonomi. Kenyataannya ada kelembagaan yang bersifat lokalitas, dan masih ada kebutuhan manusia yang bersifat sosial yang tidak dapat diukur dengan materi dan ekonomi seperti nagari di minangkabau Sumatera Barat.
Kota Batusangkar merupakan kota budaya dengan ketersediaan budaya yang ikut diperhitungkan dalam kegiatan wisata budaya. Nagari pariangan merupakan salah satu nagari yang terdapat di Batusangkar yang mana dari observasi yang telah dilakukan ditemukan masih adanya interaksi dari masyarakat dalam pengelolaan kebudayaan.

Usaha yang dilakukan oleh masyarakat dilakukan agar masyarakat desa menjadi lebih mandiri dan memajukan daerahnya. Salah satu sektor yang bisa dimanfaatkan oleh masyarakat desa adalah potensi sumber daya manusia. Karena adanya ungkapan yang menyatakan bahwasanya pariangan masih bersifat lokalitas dalam pengembangan potensi sumber dayanya.

Oleh karena itu penulis tertarik untuk menelusuri lebih lanjut lagi dalam bentuk proposal penelitian yang berjudul "Analisis Potensi Sumber Daya Manusia Nagari Pariangan Kabupaten Tanah Datar". 
KAJIAN TEORI

\section{a. Potensi Sumber Daya Manusia}

Sumber daya manusia merupakan seluruh kemampuan atau potensi penduduk yang berada di dalam suatu wilayah tertentu beserta karakteristik atau ciri demografis, sosial maupun ekonominya yang dapat dimanfaatkan untuk keperluan pembangunan.

Membahas sumber daya manusia berarti membahas penduduk dengan segala potensi kemampuannya. Potensi manusia menyangkut dua aspek, yaitu aspek kuantitas dan kualitas. Karakteristik demografi merupakan aspek kuantitatif, sumber daya manusia yang dapat digunakan untuk menggambarkan jumlah dan pertumbuhan penduduk, penyebaran penduduk dan komposisi penduduk. Karakteristik sosial dan ekonomi berhubungan dengan kualitas ( mutu) sumber daya manusia.

Desa adalah suatu kesatuan hukum dimana bertempat tinggalnya suatu masyarakat yang berkuasa mengadakan pemerintahan sendiri. Tujuan analisis data potensi sumber daya manusia (SDM) suatu desa dimaksudkan untuk mengetahui keadaan potensi sumber daya manusia, dari potensi tersebut dapat diketahui potensi pengembangannya di masa yang akan datang selain itu analisis potensi sumber daya manusia juga ditujukan untuk mengetahui faktor penghambat pengembangan sumber daya manusia yang dihadapi.

Nilai potensi suatu desa ditentukan oleh potensi yang tersedia di wilayah suatu desa, banyaknya potensi sumber daya manusia di suatu wilayah, maka indikator yang digunakan hanyalah yang dianggap erat dengan potensi desa. Berdasarkan peraturan Depdagri Nomor 12 Potensi Sumber Daya Manusia ( SDM ) dapat dinilai dari:

1) Kepadatan penduduk

Kepadatan

penduduk merupakan potensi yang dimiliki oleh suatu wilayah yang harus diketahui, berapa kepadatan penduduk yang menempati luas suatu satuan luas wilayah, yang dimaksud dengan kepadatan penduduk disini adalah kepadatan penduduk yang menempati luas satuan suatu wilayah pada masingmasing desa yang menjadi daerah penelitian. Kepadatan penduduk yaitu jumlah penduduk yang menempati tiap satuan luas wilayah, satuan luas wilayah yang umum digunakan adalah kilometer persegi $\left(\mathrm{Km}^{2}\right)$. Ada beberapa jenis kepadatan penduduk yaitu:

Besarnya kepadatan penduduk yang terdapat di suatu satuan wilayah dapat dilihat dengan menggunakan rumus sederhana yaitu:

$$
\text { Kepadatan Penduduk }=\frac{\text { Jumlah Penduduk Total }}{\text { Luas Wilayah }}
$$

Senada dengan peraturan Depdagri Nomor 12 Tahun 2007 salah satu variabel yang digunakan untuk menentukan potensi sumber daya manusia (SDM) adalah kepadatan penduduk yang menempati suatu satuan luas wilayah (Desa), dengan ketentuan penilaian, skor, dan kriteria terbagi ke dalam enam (6) kategori yang terdiri dari: 
Tabel 1. Variabel Penilaian dan

Skor Kapadatan Penduduk.

\begin{tabular}{|c|l|c|}
\hline Variabel & \multicolumn{1}{|c|}{ Penilaian } & Skor \\
\hline $\begin{array}{l}\text { Kepadatan } \\
\text { penduduk }\end{array}$ & $\begin{array}{l}\text { Bila kurang dari } \\
100 \text { jiwa/km }\end{array}$ & 2 \\
\cline { 2 - 3 } & $100-250$ & 3 \\
\cline { 2 - 3 } & $250-500$ & 4 \\
\cline { 2 - 3 } & $500-750$ & 5 \\
\cline { 2 - 3 } & $750-1000$ & 6 \\
\cline { 2 - 3 } & $\begin{array}{l}\text { Lebih dari 1000 } \\
\text { jiwa/ } / \mathrm{km}^{2}\end{array}$ & 8 \\
\hline
\end{tabular}

Sumber: Depdagri, Nomor 12 Tahun 2007

Untuk mengetahu tingkat kepadatan penduduk di suatu wilayah, berdasarkan UndangUndang No 56 tahun 1960 (pasal 1 ayat 3), adapun kategorial nya sebagai berikut:

- 1 sampai $50 \mathrm{Jiwa} / \mathrm{km}^{2}$ kategori penduduk tidak padat

- 51 sampai $250 \mathrm{Jiwa} / \mathrm{Km}^{2}$, kategori penduduk kurang padat

- 251 sampai $400 \mathrm{Jiwa} / \mathrm{Km}^{2}$, kategori Penduduk cukup padat

- $401 \mathrm{Jiwa} / \mathrm{Km}^{2}$, Kategori penduduk sangat padat

2) Jumlah kelompok usia Jumlah kelompok usia penduduk yaitu pengelompokan kelompok usia penduduk yang menempati suatu satuan wilayah berdasarkan kriteria (ukuran) tertentu. Dasar untuk menyususn kriteria (ukuran) kelompok usia dapat dilakukan dengan penggolongan usia penduduk yang menempati suatu satuan wilayah. Pengelompokan kelompok usia penduduk ini dapat dijadikan untuk dasar dalam pengambilan kebijakan dan pembuatan program dalam mengatasi masalah-masalah di bidang kependudukan.

Menurut peraturan Depdagri Nomor 12 Tahun 2007 salah satu variabel yang digunakan untuk menentukan potensi sumber daya manusia (SDM) yang ada di suatu satuan wilayah desa adalah kelompok usia penduduk. Kelompok usia penduduk yang menempati suatu satuan wilayah dapat ditentukan dan dikelompokan dengan kriteria penilaian, dan skor sebagai berikut:

Tabel 2. Variabel dan Penilaian Skor Kelompok Usia.

\begin{tabular}{|c|c|c|}
\hline Variabel & Penilaian & Skor \\
\hline \multirow{4}{*}{$\begin{array}{c}\text { Kelompok } \\
\text { usia }\end{array}$} & $\begin{array}{c}\text { Bila 25-50\% } \\
\text { penduduk usia }\end{array}$ & \\
\cline { 2 - 3 } & $0-7$ tahun & 2 \\
\cline { 2 - 3 } & $8-18$ tahun & 3 \\
\cline { 2 - 3 } & $18-56$ tahun & 8 \\
\cline { 2 - 3 } & Diatas 56 tahun & 4 \\
\hline
\end{tabular}

Sumber: Depdagri, Nomor 12 Tahun 2007

3) Tingkat pendidikan

pendidikan sangat diperlukan untuk menjamin kelangsungan hidup masyarakat ke arah yang lebih baik, guna untuk menentukan potensi sumber daya manusia suatu satuan wilayah adalah tingkat pendidikan. Dengan pendidikan yang rendah akan membawa masyarakat kepada pola hidup yang senantiasa tetap menerima normanorma lama sebagai objek tolak ukur dalam menghadapi dan menilai bahkan memandang sesuatu perubahan pada lingkungannya.

Untuk sebagai ukuran tingkat pendidikan sekolah, tingkat pendidikan sekolah diambil sepuluh tingkatan seperti yang dikemukakan oleh Nawi (1991) dalam Sri Mulyati (2004) yaitu; tidak sekolah, tidak tamat Sekolah Dasar, Tamat Sekolah Dasar, Tidak Tamat Sekolah Lanjutan Pertama, Tamat Sekolah Lanjutan Pertama, Tidak Tamat Sekolah Lanjutan Atas, Tamat Sekolah Lanjutan Atas, Tidak Tamat Sarjana Muda (D1D2), Tidak Tamat Sarjana Muda (D3), Tamat Sarjana (S1). 
Berdasarkan

peraturan

Depdagri Nomor 12 Tahun 2007 salah satu variabel yang dijadikan sebagai tolak ukur untuk menentukan tingkat potensi sumber daya manusia di suatu satuan wilayah adalah tingkat pendidikan penduduk dengan kriteria penilaian sebagai berikut:

Tabel 3. Variabel dan Penilaian

Skor Tingkat Pendidikan.

\begin{tabular}{|c|c|c|}
\hline Variabel & Penilaian & Skor \\
\hline \multirow{4}{*}{$\begin{array}{l}\text { Jumlah } \\
\text { usia 7-18 } \\
\text { tahun } \\
\text { yang } \\
\text { tidak } \\
\text { sekolah }\end{array}$} & $\begin{array}{l}\text { Bila kurang dari } 10 \% \\
\text { penduduk dari usia } 7-18 \\
\text { tahun }\end{array}$ & 3 \\
\hline & $10-25 \%$ & 2 \\
\hline & $25-50 \%$ & 1 \\
\hline & Lebih dari $75 \%$ & 0 \\
\hline \multirow{4}{*}{$\begin{array}{l}\text { Jumlah } \\
\text { usia 12- } \\
56 \text { tahun } \\
\text { yang } \\
\text { tidak } \\
\text { pernah } \\
\text { sekolah }\end{array}$} & $\begin{array}{l}\text { Bila kurang dari } 10 \% \\
\text { dari jumlah penduduk } \\
12-56 \text { tahun }\end{array}$ & 3 \\
\hline & $10-25 \%$ & 2 \\
\hline & $25-50 \%$ & 1 \\
\hline & Lebih dari $75 \%$ & 0 \\
\hline \multirow{4}{*}{$\begin{array}{l}\text { Jumlah } \\
\text { usia 12- } \\
56 \text { tahun } \\
\text { yang } \\
\text { tidak } \\
\text { tamat SD }\end{array}$} & $\begin{array}{l}\text { Bila kurang dari } 10 \% \\
\text { dari jumlah penduduk } \\
12-56 \text { tahun }\end{array}$ & 3 \\
\hline & $10-25 \%$ & 2 \\
\hline & $25-50 \%$ & 1 \\
\hline & Lebih fari $75 \%$ & 0 \\
\hline \multirow{4}{*}{$\begin{array}{l}\text { Jumlah } \\
\text { usia 18- } \\
56 \text { tahun } \\
\text { tidak } \\
\text { tamat } \\
\text { SLTP }\end{array}$} & $\begin{array}{l}\text { Bila kurang dari } 10 \% \\
\text { dari jumlah penduduk } \\
12-56 \text { tahun }\end{array}$ & 4 \\
\hline & Bila mencapai $10-25 \%$ & 3 \\
\hline & Bila mencapai $25-50 \%$ & 2 \\
\hline & Lebih dari $75 \%$ & 1 \\
\hline \multirow{4}{*}{$\begin{array}{l}\text { Jumlah } \\
\text { usia 18- } \\
56 \text { tahun } \\
\text { tidak } \\
\text { tamat } \\
\text { SLTA }\end{array}$} & $\begin{array}{l}\text { Bila kurang dari } 10 \% \\
\text { dari jumlah penduduk } \\
12-56 \text { tahun }\end{array}$ & 5 \\
\hline & Bila mencapai $10-25 \%$ & 4 \\
\hline & Bila mencapai $25-50 \%$ & 3 \\
\hline & Lebih dari $75 \%$ & 2 \\
\hline \multirow[t]{4}{*}{$\begin{array}{l}\text { Tamat } \\
\text { SLB }\end{array}$} & $\begin{array}{l}\text { Bila kurang dari } 10 \% \\
\text { dari jumlah penduduk } \\
\text { yang cacat }\end{array}$ & 5 \\
\hline & $10-25 \%$ & 7 \\
\hline & $25-50 \%$ & 9 \\
\hline & Lebih dari $75 \%$ & 10 \\
\hline
\end{tabular}

Sumber: Depdagri, Nomor 12 Tahun 2007

4) Mata Pencaharian Pokok
Mata pencaharian di daerah pedesaan pada umumnya masih berorientasi pada bidang pertanian. Pada saat ini daerah pedesaan cenderung mengarah pada pergeseran mata pencaharian dari sektor pertanian ke nonpertanian. Berbagai mata pencaharian yang dilakukan oleh penduduk di suatu satuan wilayah untuk memenuhi kebutuhan hidup sehari-hari dilaksanakan sesuai dengan kemampuan, keterampilan, pengetahuan dan pendidikan.

Sesuai dengan peraturan Depdagri Nomor 12 Tahun 2007 untuk menentukan potensi suatu satuan wilayah adalah sebaran mata pencaharian pokok penduduk yang mendiami suatu satuan wilayah dengan kriteria terbagi ke dalam delapan (8) kategori terdiri dari

Tabel 4. Variabel dan Penilaian Skor Mata Pencaharian.

\begin{tabular}{|l|l|c|}
\hline Variabel & \multicolumn{1}{|c|}{ Penilaian } & Skor \\
\hline $\begin{array}{l}\text { Jumlah } \\
\text { jenis } \\
\text { mata } \\
\text { pencahar } \\
\text { ian }\end{array}$ & $\begin{array}{l}\text { Bila sebaran mata } \\
\text { pencaharian pokok } \\
\text { penduduk kurang dari 5 } \\
\text { jenis }\end{array}$ & 3 \\
\cline { 2 - 3 } & 5-10 jenis & 4 \\
\cline { 2 - 3 } & $10-15$ jenis & 5 \\
\cline { 2 - 3 } & $15-20$ jenis & 6 \\
\cline { 2 - 3 } & $20-25$ jenis & 7 \\
\cline { 2 - 3 } & 25-30 jenis & 9 \\
\cline { 2 - 3 } & 30-35 jenis & 10 \\
\cline { 2 - 3 } & Lebih dari 35 jenis & 2007 \\
\hline
\end{tabular}

Sumber: Depdagri, Nomor 12 Tahun 2007

\section{5) Agama}

Menurut peraturan Depdagri Nomor 12 Tahun 2007. Penilaian potensi sumber daya manusia di dalamnya termuat sebaran agama yang dianut penduduk suatu satuan wilayah tempat tinggal dapat dikelompokkan dengan ketentuan penilaian sebagai berikut: 
Tabel 5. Variabel dan Penilaian Skor Agama.

\begin{tabular}{|l|l|c|}
\hline Variabel & \multicolumn{1}{|c|}{ Penilaian } & Skor \\
\hline \multirow{2}{*}{$\begin{array}{l}\text { Jumlah } \\
\text { agama } \\
\text { yang } \\
\text { dianut }\end{array}$} & $\begin{array}{l}\text { Bila sebaran penganut } \\
\text { agama hanya satu }\end{array}$ & 5 \\
\cline { 2 - 3 } & $1-2$ agama & 6 \\
\cline { 2 - 3 } & $2-3$ agama & 7 \\
\cline { 2 - 3 } & $3-4$ agama & 8 \\
\cline { 2 - 3 } & 4-5 agama & 10 \\
\cline { 2 - 3 } & $5-6$ agama & 9 \\
\hline
\end{tabular}

Sumber: Depdagri, Nomor 12 Tahun 2007

6) Kewarganegaraan dan pembauran etnis masyarakat

Bangsa Indonesia terdiri dari berbagai suku bangsa dan sub etnis, yang masing-masing memiliki kebudayaan sendiri, suku bangsa tersebut terdapat di berbagai daerah tertentu, di wilayah NKRI. Kebudayaan merupakan suatu sistem nilai yang menuntun sikap, perilaku dan gaya hidup merupakan identitas dan menjadi kebanggaan dari suku bangsa yang bersangkutan. Dalam setiap kebudayaan terdapat nilai-nilai Budaya yang tidak dapat dipengaruhi oleh kebudayaan asing, yang sering disebut local genius sebagai benteng pertahanan untuk menetralisir pengaruh negatif budaya asing.

Mengacu kepada Peraturan Depdagri Nomor 12 Tahun 2007, penilaian potensi sumber daya manusia pada satu satuan wilayah terdiri dari beberapa variabel untuk menjadi tolak ukur penilaian, salah satu variabel penilaian potensi sumber daya manusia adalah kewarganegaraan dan pembauran etnis masyarakat yang mendiami suatu satuan wilayah, dapat dikelompokan dengan ketentuan penilaian sebagai berikut:
Tabel 6. Variabel dan Penilaian Skor Kewarganegaraan.

\begin{tabular}{|l|l|l|}
\hline Variabe & Penilaian & Skor \\
\hline $\begin{array}{l}\text { Kewarg } \\
\text { anegara } \\
\text { an }\end{array}$ & $\begin{array}{l}\text { Bila semua penduduk } \\
\text { WNI }\end{array}$ & 5 \\
\cline { 2 - 3 } & $\begin{array}{l}\text { Bila pendudk WNA } \\
\text { kurang dari 10 \% }\end{array}$ & 2 \\
\cline { 2 - 3 } & $\begin{array}{l}\text { Bila penduduk WNA 5- } \\
10 \%\end{array}$ & 3 \\
\cline { 2 - 3 } & $\begin{array}{l}\text { Bila penduduk WNA } \\
\text { lebig dari 15 \% }\end{array}$ & 4 \\
\cline { 2 - 3 } & $\begin{array}{l}\text { Bila ada penduduk yang } \\
\text { dwi kewarganegaraan }\end{array}$ & 6 \\
\hline \multirow{5}{*}{$\begin{array}{l}\text { Pemba } \\
\text { uran } \\
\text { etnis } \\
\text { masyar } \\
\text { akat }\end{array}$} & $\begin{array}{l}\text { Bila penduduk berasal } \\
\text { dari 1 (satu) kelompok } \\
\text { etnis/suku bangsa }\end{array}$ & 1 \\
\cline { 2 - 3 } & 2-5 etnis/suku bangsa & 2 \\
\cline { 2 - 3 } & $5-10$ etnis/suku bangsa & 4 \\
\cline { 2 - 3 } & $10-15$ etnis/suku bangsa & 6 \\
\cline { 2 - 3 } & $15-20$ etnis/suku bangsa & 8 \\
\cline { 2 - 3 } & $\begin{array}{l}\text { Lebih dari 20 etnis/suku } \\
\text { bangsa }\end{array}$ & 10 \\
\hline
\end{tabular}

Sumber: Depdagri, Nomor 12 Tahun 2007

\section{7) Tenaga Kerja}

Semenjak dilaksanakan sakemas 2001, batas usia kerja yang semula 10 tahun diubah menjadi 15 tahun atau lebih mengikuti definisi yang dianjurkan oleh International Labour Organization (ILO). Menurut Undang-Undang Nomor 14 1969 tentang ketentuan pokok ketenagakerjaan disebutkan bahwa tenaga kerja adalah tiap-tiap orang yang mampu melakukan pekerjaan baik dalam maupun di luar hubungan kerja guna menghasilkan barang dan jasa untuk memenuhi kebutuhan.

Untuk mengukur potensi tersebut dapat dilakukan dengan ketentuan penilaian tenaga kerja masayarakat dengan kriteria sebagi berikut: 
Tabel 7. Variabel Penilaian dan Skor Tenaga Kerja.

\begin{tabular}{|c|c|c|}
\hline Variabel & Penilaian & Skor \\
\hline \multirow{5}{*}{$\begin{array}{l}\text { Penduduk } \text { Usia } \\
18-56 \text { yang } \\
\text { tidak bekerja }\end{array}$} & $\begin{array}{l}\text { Kurang } 5 \% \text { dari } \\
\text { jumlah penduduk }\end{array}$ & 5 \\
\hline & $\begin{array}{l}5-10 \% \text { dari } \\
\text { jumlah penduduk }\end{array}$ & 4 \\
\hline & $\begin{array}{l}10-25 \% \text { dari } \\
\text { jumlah penduduk }\end{array}$ & 3 \\
\hline & $\begin{array}{l}25-50 \% \text { dari } \\
\text { jumlah penduduk }\end{array}$ & 2 \\
\hline & $\begin{array}{l}\text { Lebih dari } 50 \% \\
\text { dari jumlah } \\
\text { penduduk }\end{array}$ & 1 \\
\hline \multirow{5}{*}{$\begin{array}{l}\text { Penduduk } \\
18 \quad \text { usia } \\
\text { tahun } 56 \quad \% \\
\text { bekerja }\end{array}$} & $\begin{array}{l}\text { Kurang } 5 \% \text { dari } \\
\text { jumlah penduduk }\end{array}$ & \\
\hline & $5-10 \%$ & \\
\hline & $10-25 \%$ & 5 \\
\hline & $25-50 \%$ & 7 \\
\hline & Lebih dari $50 \%$ & 10 \\
\hline \multirow[t]{7}{*}{$\begin{array}{l}\text { Angka } \\
\text { Ketergantungan } \\
\text { Kerja }\end{array}$} & $\begin{array}{lr}\text { Rasio } & \text { jumlah } \\
\text { penduduk } & 18-56 \\
\text { tahun } & \text { yang } \\
\text { bekerja dengan } & \\
\text { penduduk usia 0- } \\
56 \text { tahun keatas } \\
\text { yang } \\
\text { bekerja, tidak } \\
\text { mencapai }\end{array}$ & \\
\hline & Kurang dari $5 \%$ & 10 \\
\hline & $5-10 \%$ & 8 \\
\hline & $10-25 \%$ & 6 \\
\hline & $25-50 \%$ & 4 \\
\hline & $50-75 \%$ & 2 \\
\hline & Lebih dari $75 \%$ & 1 \\
\hline
\end{tabular}

Sumber: Depdagri, Nomor 12 Tahun 2007

\section{Rekapitulasi Skoring Data Potensi Sumber Daya Manusia Desa}

Rekapitulasi ini digunakan untuk menentukan tingkat potensi sumber daya manusia (SDM) Desa/Kelurahan dengan menjumlahkan skor tiap variabel yang diteliti.

Adapun penjabaran dari tingkat potensi terendah dan tertinggi dari sumber daya manusia yang diteliti dijabarkan pada tabel berikut
Tabel 8. Rekapitulasi Skoring Potensi Sumber Daya Manusia (SDM)

\begin{tabular}{|c|c|c|c|}
\hline \multirow[t]{2}{*}{ No } & \multirow{2}{*}{$\begin{array}{c}\text { Potensi Sumber } \\
\text { Daya Manusia } \\
\text { (SDM) }\end{array}$} & \multicolumn{2}{|c|}{ Skor } \\
\hline & & Terendah & Tertinggi \\
\hline 1 & Kepadatan & 2 & 8 \\
\hline 2 & $\begin{array}{l}\text { Perkembangan } \\
\text { Usia }\end{array}$ & 2 & 8 \\
\hline 3 & Tingkat Pendidikan & 8 & 28 \\
\hline 4 & Mata Pencaharian & 3 & 10 \\
\hline 5 & Agama & 5 & 10 \\
\hline 6 & Kewarganegaraan & 2 & 6 \\
\hline 7 & Pembaruan Etnis & 1 & 10 \\
\hline 8 & Tenaga Kerja & 3 & 25 \\
\hline & Jumlah & 26 & 105 \\
\hline
\end{tabular}

Sumber: Depdagri, Nomor 12 Tahun 2007

Berdasarkan peraturan

Depdagri Nomor 12 Tahun 2007 tentang pedoman penyusunan dan pendayagunaan data profil desa dan kelurahan maka masing-masing desa dapat dibedakan atas tingkat potensi sumber daya manusia yang dimiliki oleh masing-masing desa dengan ketentuan nilai potensi seperti yang tergambar pada tabel di bawah;

Tabel 9. Ketentuan Nilai Skoring, Tingkat Potensi Sumber Daya Manusia

\begin{tabular}{|l|l|}
\hline \multicolumn{1}{|c|}{ Jumlah Nilai Skor } & \multicolumn{1}{|c|}{ Tingkat Potensi } \\
\hline $0-85$ & Potensi Rendah \\
\hline $86-113$ & Potensi Sedang \\
\hline $114-142$ & Potensi Tinggi \\
\hline
\end{tabular}

Sumber: Depdagri, Nomor 12 Tahun 2007

\section{METODE PENELITIAN Jenis Penelitian}

Jenis penelitian Deskriptif

kuantitatif

\section{Informan Penelitian}

Seluruh jorong di Nagari Pariangan Kabupaten Tanah Datar menjadi sampel dalam penelitian ini, yaitu: Jorong Guguak, Jorong Padang Panjang, Jorong Pariangan, Jorong Sikaladi 
Tabel 10. Data, Jenis Data, Sumber

Data dan Teknik Pengumpulan

Data.

\begin{tabular}{|c|c|c|}
\hline No & Data & $\begin{array}{c}\text { Teknik } \\
\text { pengumpulan } \\
\text { data } \\
\end{array}$ \\
\hline 1 & $\begin{array}{l}\text { Kepadatan penduduk } \\
\text { Jumlah penduduk } \\
\text { Luas wilayah }\end{array}$ & $\begin{array}{l}\text { Inventarisasi } \\
\text { dan documenter }\end{array}$ \\
\hline 2 & $\begin{array}{l}\text { Struktur umur } \\
0-7 \text { tahun } \\
8-17 \text { tahun } \\
18-56 \text { tahun } \\
>56 \text { tahun }\end{array}$ & $\begin{array}{l}\text { Inventarisasi } \\
\text { dan documenter }\end{array}$ \\
\hline 3 & $\begin{array}{l}\text { Tingkat pendidikan } \\
7-18 \text { tahun yang tidak } \\
\text { sekolah } \\
12-56 \text { tahun yang tidak } \\
\text { pernah sekolah } \\
12-56 \text { tahun yang tidak } \\
\text { tamat SD } \\
18-56 \text { tahun tidak tamat } \\
\text { SLTP } \\
18-56 \text { tahun tidak tamat } \\
\text { SLTA } \\
\text { Tamat SLB }\end{array}$ & $\begin{array}{l}\text { Inventarisasi } \\
\text { dan documenter }\end{array}$ \\
\hline 4 & $\begin{array}{ll}\text { Sebaran jenis } & \text { mata } \\
\text { pencaharian pokok } & \\
\text { Jumlah jenis } & \text { mata } \\
\text { pencaharian } & \end{array}$ & $\begin{array}{l}\text { Inventarisasi } \\
\text { dan documenter }\end{array}$ \\
\hline 5 & Sebaran Agama & Inventarisasi \\
\hline 6 & $\begin{array}{l}\text { Kewarganegaraan } \\
\text { Jumlah kewarganegaraan }\end{array}$ & $\begin{array}{l}\text { Inventarisasi } \\
\text { dan documenter }\end{array}$ \\
\hline 7 & $\begin{array}{l}\text { Pembauran etnis } \\
\text { Jumlah pembauran etnis }\end{array}$ & $\begin{array}{l}\text { Inventarisasi } \\
\text { dan documenter }\end{array}$ \\
\hline 8 & $\begin{array}{l}\text { Tenaga Kerja } \\
\text { usia 18-56 tahun yang } \\
\text { tidak bekerja } \\
\text { usia 18-56 tahun yang } \\
\text { bekerja } \\
\text { Angka ketergantungan } \\
\text { kerja }\end{array}$ & $\begin{array}{l}\text { Inventarisasi } \\
\text { dan documenter }\end{array}$ \\
\hline
\end{tabular}

\section{Teknik Analisis Data}

Analisis data dalam penelitian menggunakan 2 (dua) tahap, yaitu:

\section{a. Analisis Statistik Deskriptif dengan rumus:}

$P=\frac{\text { item tersedia pada unit analisis }}{\text { keseluruhan unit analisis }} X 100 \%$

Analisis digunakan untuk menganalisis, mengidentifikasi, beberapa variabel yang diteliti berdasarkan permendagri, yang meliputi: kepadatan penduduk, kelompok usia, tingkat pendidikan, sebaran jenis mata pencaharian pokok, sebaran agama, kewarganegaraan, pembauran etnis, tenaga kerja.

Kemudian dilanjutkan dengan melakukan penskoran terhadap masing-masing variabel dan menentukan potensi sumber daya manusia. Dengan ketentuan potensi tinggi, potensi sedang, dan potensi rendah hasilnya disesuaikan dengan penilaian potensi sumber daya manusia yang dikeluarkan Depdagri Nomor 12 Tahun 2007 tentang pedoman penyusunan dan pendayagunaan data profil desa dan kelurahan. Untuk lebih jelasnya dapat dilihat di tabel berikut ini:

Tabel 11. Analisis Potensi Sumber Daya Manusia

\begin{tabular}{|l|l|l|l|}
\hline $\begin{array}{l}\text { Analisis } \\
\text { Potensi } \\
\text { SDM }\end{array}$ & $\begin{array}{l}\text { Potensi } \\
\text { SDM } \\
\text { Tinggi }\end{array}$ & & $>132$ \\
\cline { 2 - 4 } & Potensi & Antara 60 \% & Antara \\
& $\begin{array}{l}\text { SDM } \\
\text { Sedang }\end{array}$ & $\begin{array}{l}\text { - 80 \% dari } \\
\text { skor } \\
\text { maksimal }\end{array}$ & $\begin{array}{l}99 \\
132\end{array}$ \\
& Potensi & $\begin{array}{l}<60 \% \text { dari } \\
\text { skor }\end{array}$ & $<99$ \\
& SDM \\
& Rendah & maksimal & \\
\hline
\end{tabular}

Sumber: Depdagri, Nomor 12 Tahun 2007

Analisa data yang digunakan untuk menganalisa data kualitatif dalam penelitian ini adalah analisa yang dilakukan dalam analisis data ini adalah penggolongan data, penyajian data, dan verifikasi data.data dilapangan Model Miles and Huberman.

1. Reduksi Data

2. Interpretasi Data

3. Pengambilan Keputusan 
HASIL PENELITIAN

\section{Kepadatan Penduduk}

Persebaran penduduk di masing-masing satuan wilayah di Nagari Pariangan pada dasarnya tidak sama rata. Jumlah total penduduk yang mendiami wilayah administrasi Nagari Pariangan berjumlah 5649 jiwa dan jumlah total luas wilayah administrasi Nagari Pariangan 17,92 km. Untuk Jorong Guguak kepadatan penduduk 152 jiwa/km. Untuk Jorong Padang Panjang kepadatan penduduk 337 jiwa/km. Untuk Jorong Pariangan kepadatan penduduk $347 \mathrm{jiwa} / \mathrm{km}$, untuk Jorong Sikaladi kepadatan penduduk 464 jiwa/km. Dari semua jorong yang ada di Nagari Pariangan jorong Sikaladi memiliki kepadatan penduduk yang paling tinggi di bandingkan dengan jorong yang lain.

\section{Kelompok Usia}

Pemberian skor pada jumlah kelompok usia yang menempati suatu satuan wilayah jorong yang ada di Nagari Pariangan mengacu kepada peraturan Depdagri No 12 tahun 2007, yang dilihat dari kelompok umur 0- 7 tahun, 8-17 tahun, 18 - 56 tahun, dan 56 tahun.

Jumlah kelompok usia

penduduk/masyarakat yang mendiami untuk satuan wilayah Jorong yang ada di Nagari Pariangan Dilihat dari kelompok umur $0-7$ tahun penduduk Jorong Guguak 17,2 \% dari total jumlah penduduk kelompok umur 0-7 tahun secara keseluruhan, jorong Padang Panjang 15,3\% dari total jumlah penduduk kelompok umur 07 tahun secara keseluruhan, jorong Pariangan 12,8\% dari total jumlah penduduk kelompok umur 0-7 tahun secara keseluruhan, jorong Sikaladi $14,6 \%$ dari total jumlah penduduk kelompok umur 0-7 tahun secara keseluruhan.

Jumlah Kelompok usia 8-17 tahun jorong Guguak 28,8\% dari total jumlah kelompok umur 8-17 tahun secara keseluruhan, jorong Padang Panjang 25\% dari total jumlah kelompok umur 8-17 tahun secara keseluruhan, jorong Pariangan 24,3\% dari total jumlah kelompok umur 8-17 tahun secara keseluruhan, jorong Sikaladi 25,2\% dari total jumlah kelompok umur 817 tahun secara keseluruhan.

Jumlah kelompok usia 18-56 tahun jorong Guguak 37,9\% dari total jumlah kelompok umur 18-56 tahun secara keseluruhan, jorong Padang Panjang 47,1\% dari total jumlah kelompok umur 18-56 tahun secara keseluruhan, jorong Pariangan 47,6\% dari total jumlah kelompok umur 18-56 tahun secara keseluruhan, jorong Sikaladi 50,2\% dari total jumlah kelompok umur 18-56 tahun secara keseluruhan.

Jumlah kelompok usia lebih dari 56 tahun jorong Guguak 16,1\% dari total jumlah kelompok umur lebih dari 56 tahun secara keseluruhan, jorong Padang Panjang $12,6 \%$ dari total jumlah kelompok umur lebih dari 56 tahun secara keseluruhan, jorong Pariangan $15,3 \%$ dari total jumlah kelompok umur lebih dari 56 tahun secara keseluruhan, jorong Sikaladi 10\% dari total jumlah kelompok umur lebig dari 56 tahun secara keseluruhan. 


\section{Tingkat Pendidikan}

Tingkat pendidikan penduduk dapat dilihat dari jumlah usia 7-18 tahun yang tidak sekolah, jorong Pariangan 0,49\%, jorong Padang Panjang $0,64 \%$, jorong Pariangan tidak ada, jorong Sikaladi 0,50\%.

Tingkat pendidikan penduduk dilihat dari jumlah usia 12- 56 tahun yang tidak pernah sekolah, jorong Guguak 7,6\%, jorong Padang Panjang $0,96 \%$, jorong Pariangan $2,12 \%$, jorong Sikaladi 3,83\%.

Tingkat pendidikan penduduk dilihat dari jumlah usia 12-56 tahun yang tidak tamat SD, jorong Guguak 8,13\%, jorong Padang Panjang $1,67 \%$, jorong Pariangan $1,41 \%$, jorong Sikaladi 2,89\%.

Tingkat pendidikan penduduk dilihat dari jumlah usia 18-56 tahun yang tidak tamat SLTP, jorong Guguak 28,56\%, jorong Padang Panjang 3,64\%, jorong Pariangan $6,59 \%$, jorong Sikaladi 8,08\%.

Tingkat pendidikan penduduk dilihat dari jumlah usia 18-56 tahun yang tidak tamat SLTA, jorong Guguak 13,75\%, jorong Padang Panjang 3,29\%, jorong Pariangan 3,22\%, jorong Sikaladi 2,65\%.

Tingkat pendidikan penduduk dilihat dari Jumlah yang tamat SLB semua jorong di Nagari pariangan tidak ada yang tamat SLB.

\section{Mata Pencaharian}

Sebagian besarmasyarakatnya bermata pencaharian sebagai petani, peternak, dan di samping itu ada juga masyarakat yang mempunyai pekerjaan selain petani yakni, PNS, peternak ayam, pedagang, pegawai BUMN, tukang bengkel, bidan, pensiunan, tukang rumah dari keterangan tersebut jumlah mata pencaharian pokok masyarakat yang ada di jorong Nagari Pariangan berjumlah 6 mata pencaharian pokok.

\section{Agama}

Hasil jumlah sebaran agama yang dianut masyarakat masingmasing jorong di Nagari Pariangan semua jorong beragama Islam.

\section{Kewarganegaraan}

Kewarganegaraan masyarakat masing-masing jorong di Nagari Pariangan, setiap jorong di Nagari Pariangan penduduk/masyarakatnya berkewarganegaraan Indonesia.

\section{Pembauran Etnis}

Setiap jorong di Nagari Pariangan pembauran etnis/suku bangsa penduduk/masyarakatnya hanya berasal dari satu kelompok etnis/ suku bangsa yakni suku minang.

\section{Tenaga Kerja}

Penduduk usia 18-56 tahun yang tidak bekerja, Jorong Guguak $1,62 \%$, jorong Padang Panjang $1,63 \%$, jorong Pariangan $0,42 \%$, jorong Sikaladi 0,50\%. Penduduk usia 18-56 tahun yang bekerja, jorong Guguak 98\%, jorong Padang Panjang 98,9\%, jorong Pariangan 99,5\%, jorong Sikaladi 99,4\%.

Angka ketergantungan kerja penduduk usia 18-56 tahun yang bekerja dengan penduduk 0-56 yang tidak bekerja, jorong Guguak 66,9\%, jorong Padang Panjang $88,5 \%$, jorong Pariangan 97,3\%, jorong Sikaladi 88,5 \%. 
PENUTUP

Kesimpulan

Penilaian kepadatan penduduk masing-masing jorong di Nagari Pariangan lebih dari $100 \mathrm{jiwa} / \mathrm{km}^{2}$.

Penilaian jumlah kelompok usia penduduk masing-masing jorong di Nagari Pariangan 25-50\% penduduk berusia 18-56 tahun. Penilaian tingkat pendidikan masyarakat masing-masing jorong di Nagari Pariangan kelompok umur 7-18 tahun yang tidak sekolah kurang dari $10 \%$ dari jumlah total penduduk kelompok umur 7-18 tahun. Kelompok umur 12-56 tahun yang tidak pernah sekolah pada masing-masing jorong di Nagari Pariangan kurang dari $10 \%$. Penduduk masing-masing jorong kelompok umur 12-56 tahun tidak tamat SD kurang dari $10 \%$ dari jumlah total penduduk kelompok umur 12-56 tahun. Kelompok umur 12-56 tahun yang tidak tamat SLTP masing-masing jorong di Nagari Paraiangan kurang dari $30 \%$. Sedangkan penduduk kelompok umur 18-56 tahun masing-masing jorong di Nagari Pariangan yang tidak tamat SLTA kurang dari $15 \%$.

Penilaian jumlah sebaran mata pencaharian pokok penduduk masing-masing jorong Nagari Pariangan berkisar 5-10 jenis mata pencaharian pokok, sebagian besar penduduk bermata pencaharian petani, peternak,pedagang.

Penilaian sebaran agama penduduk masing-masing jorong di Nagari Pariangan, semua penduduk beragama islam.

Penilaian kewarganegaraan penduduk masing-masing jorong di Nagari Pariangan, semua penduduk berkewarganegaraan Indonesia (WNI). $\begin{array}{cc}\text { Penilaian } & \text { pembauran } \\ \text { etnis/suku bangsa masyarakat }\end{array}$ masing-masing jorong di Nagari Pariangan, semua penduduk berasal dari satu etnis/suku bangsa yakni suku Minang.

Penilaian tenaga kerja di masing-masing jorong di Nagari Pariangan dilihat dari kelompok umur 18-56 tahun penduduk masing-masing jorong yang tidak bekerja rata-rata di bawah $5 \%$. Penduduk kelompok umur 18-56 tahun yang bekerja pada masingmasing jorong di Nagari Pariangan lebih dari $50 \%$, sedangkan angka ketergantungan kerja penduduk usia 18-56 tahun yang bekerja dengan penduduk 0-56 tahun ke atas yang tidak bekerja pada masing-masing jorong di Nagari Pariangan mencapai $50-90 \%$.

\section{Saran}

Pembangunan suatu wilayah administrasi Nagari Pariangan perlu direncanakan atas dasar potensi geografis, yang mencakup fisik, sumber daya manusia, sosio kulturnya.

Peningkatan sumber daya manusia dan IPTEK merupakan sasaran utama pembangunan agar berkelanjutan dan manfaatnya dapat segera dirasakan oleh sebagian besar masyarakat nagari.

Salah satu usaha untuk memacu percepatan perkembangan dan pertumbuhan ekonomi daerah ini diusulkan adanya usaha pemberdayaan melalui program penyuluhan, yang berpola tanaman pangan dan perkebunan. Hal ini sesuai dengan potensi daerah dan kesesuian lahan serta animo masyarakat yang tinggi.

Zonasi wilayah geografis dan sebaran penduduk dapat dijadikan 
sebagai kebijakan pembangunan spasial- sektoral yang berkelanjutan agar segera tercapai demi kesejahteraan masyarakat.

\section{DAFTAR PUSTAKA}

Depdagri Nomor 12 Tahun 2007

oleh Nawi (1991) dalam Sri Mulyati (2004)

Undang-Undang Nomor 141969 tentang ketentuan pokok ketenagakerjaan

Sugiyono. 2013. Metode Penelitian Kuantitatif Kualitatif dan $R \& D$. Bandung : Alfabeta.

Tanah Datar dalam Angka 2014.

[UU RI] Undang-undang Republik Indonesia. 2014 . Undangundang Republik Indonesia nomor 10 tahun 2014 tentang: Desa.Jakarta: Pemerintah Republik Indonesia. 